\title{
A Learning Model-Oriented in Soft Skill Management to Improve Entrepreneurship Skill of Vocational High School Student
}

\author{
Atika $^{1}$ \\ ${ }^{1}$ Department of Home Economics, Semarang State University, Semarang, Indonesia \\ atika@mail.unnes.ac.id
}

Keywords: Soft Skills Management, Entrepreneurship, Project-based Learning, Vocational High School.

\begin{abstract}
The unemployment rate from Vocational High School graduate can be reduced by maximizing the role of Vocational High School to prepare the student to be an entrepreneur. It can be done by strengthening students' communication skill to interact with the environment suitable for their competence. That skill can be rehearsed by using a learning model oriented in soft skill management, that is a Project-based Learning integrated with Entrepreneurship. The objective of this research is to measure students' communication skill shown through immediate service for society. This research focuses on a specific competence related to motorcycle tune-up. The learning process supported a project to offer motorcycle tune-up service for the community. This research used quasi-experiment method. The subjects of this research were the students of XII TSM 1 (XII Low Vehicle Engineer 1) as Experimental Group and students of XII TSM 2 as Control Group. The result shows that this learning model improves students' communication skill. In the scale of 1 to 5 , the students' achievement improves at 2.54 point. Both experimental and control groups present a significantly different result, with t of 28.3 and $t$ table of 2.14. The experimental group can act as the workshop manager, execute the standard of service, exhibit leadership, find some service tricks and develop them creatively, implement the first-rate service and report the result orally. Whereas the control group participated in classic learning only without conducting immediate entrepreneurship practice and project-oriented education related to the material.
\end{abstract}

\section{INTRODUCTION}

The objective of vocational high school is basically to reduce the unemployment rate in Indonesia. However, most of the unemployment come from Vocational High School graduate. The data from Statistics Indonesia (2018) shows that the Open Unemployment Rate from Vocational High School is still the highest compared to other educational institutions, which is $11.24 \%$. Vocational High School Statistics (2018:10) shows that there are 13,710 Vocational High Schools in Indonesia in 2017-2018, with 4,904,031 students and 1,300,521 graduates. The Directorate of Vocational High School (2018) shows some data regarding the study program of Vocational High School in Indonesia. It shows that the number of Vocational High School in Indonesia which offer Automotive Engineer program is still the highest, namely 5,736. It can be assumed that most of the unemployment graduate from that program since the number of the automotive industry in Indonesia is low. The Ministry of Industry (2015) reveal that the number of the automotive industry in Indonesia is lower than Thailand; for example, Indonesia only has 1,550 automotive company while Thailand has 2,200 companies. That number is not sufficient to accommodate the 700,000 students who graduate from the automotive program each year.

Vocational High School is aimed to prepare the graduates to be an entrepreneur. It is a very strategic goal to help to reduce the unemployment rate from vocational high school, especially automotive engineer program. Students who can implement entrepreneurship in the automotive program have a higher potential to succeed. Triatmono.info (2017) mentions that the motorcycle sale is high and stable 
based on the data gained in 2011-2016, namely $8,028,267,7,137,663,7,743,879,7,867,195$, and 4,351,397 unit (until September 2016). It can be concluded that if the number of the vehicle in the market is high, the need for maintenance and service will also be high. Opening a workshop is one of the solutions to reduce unemployment from the automotive program.

Students' entrepreneurship skill becomes real obstacles after they graduate. If their skill is inadequate, they will miss the opportunity. Their soft skill, especially communication skill, is needed to overcome this obstacle. Mastering this soft skill will be helpful to improve their entrepreneurship skill since it is related to communication skill, innovative thinking, courage, and cooperation. According to Pangaribuan (2016), soft skill training is useful to develop the attitude, behaviour, and individual characters. In detail, the skills needed to develop entrepreneurship skill in automotive are: (1) understanding the job description and performing well; (2) executing the standard of service in the workshop; (3) exhibiting leadership; (4) creating some tricks and be creative while giving service; (5) providing the first-rate service; and (6) reporting the result.

A learning model oriented in soft skill management, such as project-based learning integrated with entrepreneurship, is done to help students of automotive program improving their entrepreneurship skill, especially in motorcycle tuneup competence. The characteristics of project-based learning are complete and systematic, such as understanding a topic, setting a plan from the issue, arranging a project, working on the project, and acting as a real entrepreneur in a learning process. These activities are believed to be beneficial to improve students' entrepreneurship skill.

The objective of this research is to measure students' communication skill and prepare them to be an entrepreneur through a learning model oriented in soft skill management, that is project-based learning integrated with entrepreneurship. This research focuses on a specific competence related to motorcycle tune-up. The learning process is conducted by creating a tune-up service project directed to society. This research used the quasiexperiment method with six students from XII TSM 1 as experimental group and six students from XII
TSM 2 as a control group in SMK NU 06 Muallimin Weleri Kendal.

\section{RESEARCH METHOD}

Experiment method was used in this research, whereas the research design used a quasi-experiment (pretest-postest with control group design) in which experimental and control groups were examined. The learning results of both groups were compared using the t-test.

Table 1. Research Design

\begin{tabular}{lll}
\hline Pre-Test & Treatment & Post-Test \\
\hline O1 & $\mathrm{X}$ & $\mathrm{O} 2$ \\
$\mathrm{O} 3$ & - & $\mathrm{O} 4$ \\
\hline
\end{tabular}

$\mathrm{O} 1=$ Pre-test result of experimental group

$\mathrm{O} 2$ = Post-test result of experimental group

$\mathrm{O} 3$ = Pre-test result of control group

$\mathrm{O} 4$ = Post-test result of control group

$\mathrm{X}=$ Treatment with media implementation

(Sugiyono, 2009:116).

Research stages:

a. Determining research objectives.

b. Choosing the learning material which supports the objectives.

c. Determining the learning method and model and preparing the material.

d. Compiling the Lesson Plan.

e. Preparing the media.

f. Preparing and validating the instrument.

g. Conducting a pre-test for both experimental and control group.

h. Analyzing pre-test data.

i. The learning process for a control group using the classic method.

j. The learning process for the experimental group using project-based learning method integrated with entrepreneurship. At this stage, the students participate in a project oriented-leaning which focus on motorcycle tune-up service. The learning process is divided into six steps, as follow:

1) Discussing the learning material.

2) Setting the service schedule.

3) Planning the program. 
4) Simulating the program and monitoring. At this step, students work in the workshop to serve the customers. Students worked in a group consisted of customer service, service advisor, mechanic, and part men. One student should act as a customer in the workshop. The students played each role alternately.

5) Serving the society directly based on the schedule and plans. The teacher controlled and assisted the activity.

6) Giving evaluation and delivering the report.

k. Conducting post-test for both groups.

1. Comparing the post-test result of both groups.

\section{RESULT AND DISCUSSION}

T-test result from pre-test can be gained if both groups do not show a significant difference. The initial pre-test result between the experimental and control group can be seen in the table below:

Table 2. T-test Result for Pre-test

\begin{tabular}{lcccc}
\hline \multicolumn{1}{c}{ Group } & Average & $\mathrm{t}_{\text {count }}$ & $\mathrm{t}_{\text {table }}$ & Criteria \\
\hline Experimental & 1.31 & - & \multirow{2}{*}{2.14} & No \\
Control & 1.27 & 0.38 & & Difference \\
\hline
\end{tabular}

The result shows no significant difference because both groups achieve similar treatment during the learning process related to motorcycle tune-up and entrepreneurship. The learning process was conducted traditionally without any modification or innovation to improve the managerial skill so that students' soft ability from both groups was low. Some changes are needed to improve their entrepreneurship skill. Samsudi (2014:314) expresses that according to the principal, teachers, and the instructors, it is essential to develop some innovations in learning for the productive program in Vocational High School.

T-test result from post-test can be gained if both groups show significant difference. The initial posttest effect between the experimental and control group can be seen in the table below:

Table 3. T-test Result for Post-test

\begin{tabular}{lcccc}
\hline \multicolumn{1}{c}{ Group } & Average & $\mathrm{t}_{\text {count }}$ & $\mathrm{t}_{\text {table }}$ & Criteria \\
\hline Experimental & 3.85 & \multirow{2}{*}{28.34} & 2.14 & Different \\
Control & 1.27 & & & \\
\hline
\end{tabular}

There is a significant difference between the experimental and control group. In the scale of 1 to 5 , the average score of the experimental group is 3.85 while the average score control group is 1.27 . It is shown that the t-count is 28.34 from the available t-table. The result is significantly different due to some reasons. It is assumed that there is no improvement in the control group because they did not achieve special treatment to improve their communication skill through immediate practice to society. In other words, they did not learn how to plan the program and conduct a quick training so that their grade did not change.

The average point of the experimental group improved significantly after they achieved a special treatment in the group with project-based learning integrated with entrepreneurship. The average score of their pre-test is 1.31 , while the post-test point is 3.85. This improvement happens because they learn how to make a business plan from choosing promotion method to evaluation of the program, act as a particular position in the workshop, create the workshop layout based on its design, be active in preparing the tools, execute the standard of service, use the work order, show their accomplishment in the workshop, and report the result.

Bell (2010:39) notes, "Project-Based Learning $(\mathrm{PBL})$ is an innovative approach to learning that teaches a multitude of strategies critical for success in the twenty-first century. Students drive their learning through inquiry, as well as work collaboratively to research and create projects that reflect their knowledge."

Setiarini (2013:154) expresses that business plan given to the students as the media of economy learning model in Senior High School 1 Wonosobo for the $10^{\text {th }}$ grader in entrepreneurship material, is very useful for the implementation of entrepreneurship.

This learning activity helps the students to practice: (1) leadership, that is the ability to lead and give command to other group members so that the plan runs well; (2) confidence and responsibility, that is students' constancy in doing and finishing their job; (3) courage to take risk, that is the students' courage to suggest and offer a solution to change a component based on their analysis; (4) creativity and innovation, that is students' skill to show their creativity through promotion; and (5) the ability to 
give first-rate service for the customer related to perceptiveness, reliability to work and provide service warranty. The previous research supports this result by Naufalin et al. (2016:72) which expresses, "Students experienced the increased soft skills when they were fully involved in the implementation."

Rahayu (2012: 99) in her research also supports that school should be designed to be a particular environment where the students feel as if they are put in a real situation to practice entrepreneurship. However, Sugiharsono (2014: 71) says that budget is one of the obstacles to implement entrepreneurship learning in Vocational High School.

The improvement of students' skill in giving service for the society comprising some aspects, and supported by the result of previous results shows that the learning model oriented in soft skill management can improve the readiness of Vocational High School students to be an entrepreneur.

\section{CONCLUSION}

The learning model oriented in soft skill management improves the students' communication skill to prepare the students as entrepreneurs. It is proven that in the scale of 1 to 5 , the students' achievement improves at 2.54 point. Both experimental and control groups present a significantly different result, with $t$ of 28.3 and $t$ table of 2.14. The experimental group can act as the workshop manager, execute the standard of service, exhibit leadership, find some service tricks and develop them creatively, implement the first-rate service and report the result orally. Whereas the control group participate in classic learning only without conducting immediate entrepreneur practice and project-oriented education related to the material.

\section{REFERENCES}

Bell, Stephanie. (2010). Project-based Learning for $21^{\text {st }}$ Century; Skills for the Future. The Clearing House. 2(83), 39-43.

Badan Pusat Statistik. (2018). Tingkat Pengangguran Terbuka (TPT) sebesar 5,34 persen. Retrieved from https://www.bps.go.id/pressrelease/2018/11/05/1485/a gustus-2018--tingkat-pengangguran-terbuka--tpt-sebesar-5-34-persen.html. (11/10/2019: 09.55 WIB)
Kemendikbud. (2018). Data Statistik SMK. Jakarta: Kementrian Pendidikan dan Kebudayaan.

Direktorat Pembinaan SMK. (2016). Data Pokok SMK. Jakarta: Kemendikbud.

Detik Finance. (2016). Pengangguran Terbesar RI Adalah Lulusan SMK. Retrieved from http://finance.detik.com/berita-ekonomi-bisnis/d3203625/pengangguran terbesar-ri-adalah-lulusan-smk.

Naufalin, R.L., Dinanti, A., \& Krisnaresanti, A. (2016). Experimental Learning Model on Entrepreneurship Subject to Improve Student's Soft Skills. Dinamika Pendidikan, 11 (1), 65-73.

Pangaribuan. (2016). Upah Yang Tinggi atau Pelatihan Soft Skills?. Retrieved from https://www.kompasiana.com/romariopangaribuan/590 6f7f928b0bda31ae5662e/upah-yang-tinggi-ataupelatihan-soft-skills. (10/10/2018: 09.14 WIB)

Rahayu, W., Patmi. (2012). Sikap Kewirausahaan Sekolah Menengah Kejuruan. Jurnal Ilmu Pendidikan, 18 (1), 98-104.

Samsudi. (2014). Pengembangan Model Pembelajaran Progam Produktif SMK untuk Membentuk Karakter Kewirausahaan Lulusan. Jurnal Cakrawala Pendidikan, 33 (2), 307-314.

Sugiharsono, S., Lestari, B., \& Sagoro, M.E., (2014). Implementasi Pendidikan Kewirausahaan di SMA dan SMK Manyongsong Implementasi Kurikulum 2013. Jurnal Kependidikan, 44(1), 64-72.

Sugiyono. (2009). Metode Penelitian Pandidikan (Pendekatan Kuantitatif, Kualitatif dan $R \& D$ ). Bandung: Alfabeta.

Triatmono Info. (2017). Data Penjualan Sepeda Motor 2005-2016. Retrieved from http://triatmono.info/datapenjualan-tahun-2012/data-penjualan-motor-tahun2005/. (1/1/2017:09.45 WIB) 